\title{
Castleman Disease Localized On The Right And Left Buccal Mucosa
}

\author{
Să̆ Ve Sol Bukkal Mukoza Yerleşimli Castleman Hastalığı \\ Caner kılıçç, Metin Kaya ${ }^{2}$, Ela Cömert ${ }^{1}$, Ümit Tunçel ${ }^{1}$, Nazan Bozdoğan ${ }^{3}$ \\ ${ }^{1}$ Ankara Onkoloji Eğitim Araştırma Hastanesi, Kulak Burun Boğaz Kliniği, Ankara, Türkiye \\ ${ }^{2}$ Batman Devlet Hastanesi \\ ${ }^{3}$ Ankara Onkoloji Eğitim Araştırma Hastanesi, Patoloji Kliniği, Ankara, Türkiye
}

Dergiye ulaşma tarihi: 15/11/2014, Dergiye kabul tarihi: 30/04/2015, Doi: 10.5505/aot.2015.72693

\section{ÖZET}

Castleman hastalığ $1(\mathrm{CH})$, en sık mediastende asemptomatik kitle olarak görülen lenfoproliferatif bir hastalıktır. Baş boyun bölgesinde ise en sık boyun da görülür. Oral kavite de yerleşimi nadirdir. Tedavisinde cerrahi eksizyon uygulanır. Bu makalede sağ ve sol yanak mukoza altında, giderek büyüyen şişlik şikayeti ile tarafımıza başvuran ve histopatolojik tanısı castleman hastalığı- plazma hücreli tip olarak raporlanan, non hodgkin lenfoma (NHL) öyküsü olan hasta, literatür eşliğinde sunulmuştur.

Anahtar Kelimeler: Bukkal Mukoza, Castleman Hastalığı, Non hodgkin lenfoma

\section{ABSTRACT}

Castleman disease (CD) is a lymphoproliferative disorder that is most frequently seen as an asymptomatic mass in the mediastinum. Among the head and neck region, the neck is the most frequent localization. It is seldom localized in the oral cavity. Surgical excision is the primary choice of treatment. The current study presents a patient with previous non-Hodgkin Lymphoma (NHL) history, who was complaining of a mass gradually increasing in size beneath the right and left buccal mucosa and a histopathological diagnosis of Castleman disease - plasma cell type. The related literature is also reviewed.

Key words: Buccal Mucosa, Castleman Disease, Non Hodgkin Lymphoma

\section{Introduction}

Castleman disease (CD) is a lymphoproliferative disorder characterized by lymphoid tissue hyperplasia. It is also called angiomatous lymphoid hamartoma. Histopathologically, the disease is classified as hyalinic vascular, plasma cell, and mixed variants. The most frequent subtype is the hyalinic variant, which has a low recurrence rate. The plasma cell subtype is more aggressive and is concomitant with systemic diseases (1). It is most commonly localized in the mediastinum as an asymptomatic mass. Among the head and neck region, the neck is the most frequent localization (2). Chronic inflammation and immune insufficiency are responsible for the etiology and it is seen concomitantly with autoimmune diseases like pemphigus.3 Clinically, isolated or multicentric subtypes can be seen. Isolated subtypes generally are seen in younger patients and multicentric types in older patients. In the treatment, total or near total surgical excision can be performed according the localization (4). Radiotherapy may be used as an adjuvant or a mass reductive modality (5). We herein report a patient with previous NHL history, who had CD lesions localized beneath right and left buccal mucosa. We present the treatment of this patient who shows a rare localization of the disease and a review of the literature as well.

\section{Case Report}

A 64-year-old male patient who had gradually growing masses in the oral cavity (beneath both sides the buccal mucosa) was admitted to the Ankara Oncology Teaching and Research Hospital Ear Nose Throat Department. The physical exam revealed rigid masses with smooth surfaces, and reduced mobility was observed under the right and left buccal mucosa (Figure 1). No other abnormalities were found.

Systemic signs such as fever and sweating were absent. Laboratory tests and viral markers were normal. Systemic physical exams were normal, as well. According to the patient's medical history,

Adress for correspondence: Caner Kılıç, Ankara Onkoloji Eğitim Araștırma Hastanesi KBB Kliniği, Ankara, Türkiye

e-mali: canerkilic80@gmail.com

Available at www.actaoncologicaturcica.com

Copyright @Ankara Onkoloji Hastanesi 
he had received chemotherapy almost nine years before due to diffuse B cell NHL. He underwent lymph node excision in his neck 4.5 years prior and the specimen revealed plasma cell type CD. Radiological examination was natural.

Horizontal incisions were made on the mucosa transorally above the masses to diagnose and treat the patient. Minor salivary glands under the mucosa were lateralized and masses with smooth surfaces adhered to the surrounding tissue were observed.

The mass under the left buccal mucosa and near total excision of the mass under the right buccal mucosa were totally excised. The histopathological examination of both specimens revealed Castleman disease with plasma cell subtype (Figure 2). Neither adjuvant radio nor chemotherapy was recommended by oncology departments. During the threeyear follow up, no recurrence was occurred.

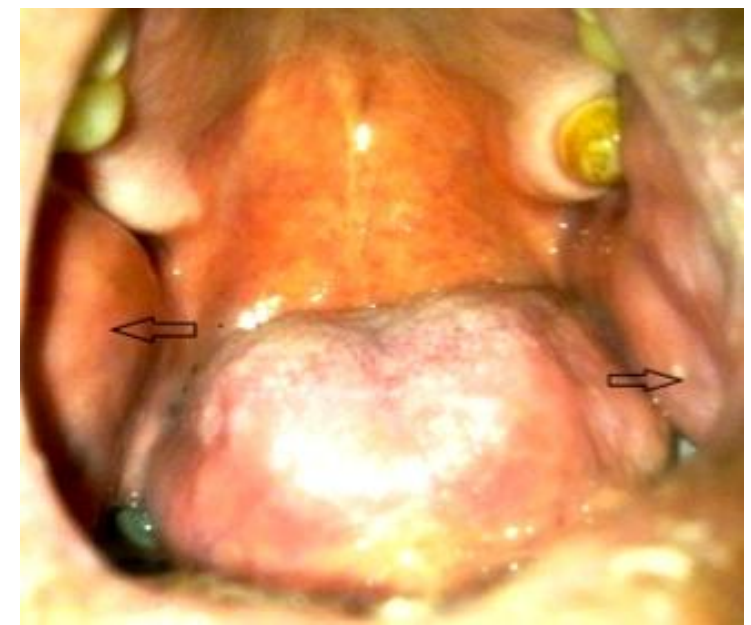

Figure 1: Masses under the right and left buccal mucosa.

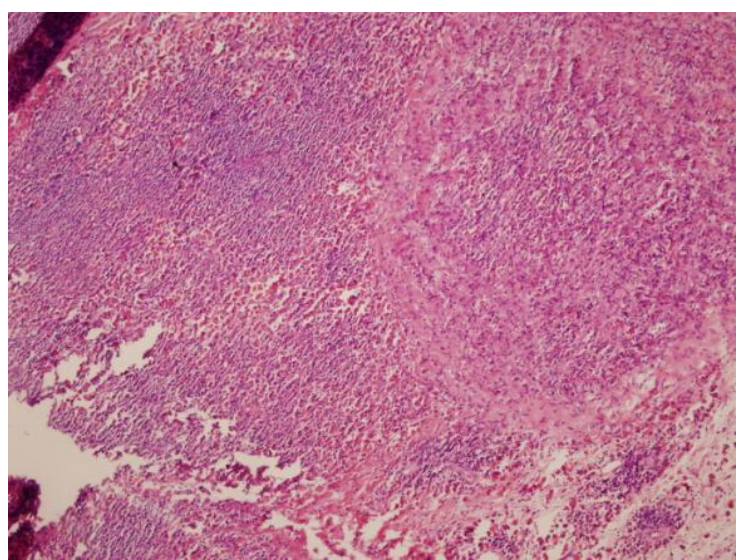

Figure 2: Castleman disease with plasma cell subtype

\section{Discussion}

Castleman disease was first described in a patient as an isolated mediastinal mass. It is also called angiofollicular lymph node hyperplasia, giant lymph node hyperplasia, lymph node hamartoma, and benign giant lymphoma. It is seen equally among the genders and more frequently in young adults (1). The etiology is not clearly identified. However, it may be seen concomitantly with other disorders such as NHL, multiple myeloma, B cell lymphoma, Kaposi's sarcoma (6). It was reported that viral infections such as HHV-8, HIV, EBV. ${ }^{7}$ The patient presented herein received treatment for NHL nine years prior, and he is still in remission.

Depending on clinical presentation, the disease can also be divided into isolated or multicentric subtypes. The multicentric type is generally seen with other systemic diseases and shows progress more aggressively (5). Histopathologically, CD is also classified into three different subtypes as vascular, plasma cell, and mixed (1). The plasma cell type accounts for almost $10 \%$ of the cases, is generally multicentric, and is associated with systemic symptoms such as fever, sweating, elevated sedimentation rate, anemia, and thrombocytopenia. Although the current patient's lesions were multicentric, and histopathologically of the plasma cell type, he did not present systemic signs.

Castleman disease that occurs in the head and neck region, is most frequently seen in the neck, and it was reported to be rarely seen in the parotis, mouth floor, and oral cavity, as well (2). One study in the literature 
reported a study of 14 patients with $\mathrm{CD}$ in the neck, in which the mass was found unilaterally and at level II all the patients (8). Karakoc et al. reported that in a patient with dysphagia, a postoperative pathological specimen revealed $\mathrm{CD}$, which was thought to be parapharangeal schwannoma preoperatively (9). In a patient who had been followed-up for cervical mass and treated with preoperative embolization due to enhanced peripheral vascularization in the MRI, the postoperative specimen showed CD (10). Deshmukh et al. reported that a patient who had been diagnosed with squamous cell carcinoma of the tongue with stage T1N3M0 had undergone cervical dissection. After the dissection, the specimen revealed $\mathrm{CD}$, so the authors accepted the stage of the disease as T1N0M0 (11). These studies suggest that CD in the neck localized laterally may mimic many different disorders (2). Three years ago, the current patient underwent cervical node biopsy at level II and the specimen showed CD plasma cell subtype.

CD localized in the oral cavity is rarely described. There is only one case of a welldefined submucosal mass unilaterally beneath the buccal mucosa in literature (12). The current case was admitted to our department with asymptomatic masses localized under the right and left buccal mucosa. A case with masses with such localization is presented for the first time in the literature.

Histopathological confirmation is needed for the definitive diagnosis. Fine needle aspiration biopsy has no diagnostic value, and the diagnosis is made by incisional or excisional biopsy. Total or near total excision should be performed for the treatment (4). Corticosteroids should be added in the therapy of patients with systemic symptoms. Due to autoimmunity being blamed for the etiology, cytotoxic drugs or immunomodilators such as interferon and intravenous immunoglobulin are used (13). The recurrence rate is high in the plasma subtype, and thus, chemotherapy and radiotherapy (RT) can be added. It was reported that a partial or complete response can be obtained in the treatment of CD with 40-50 Gy. doses of radiotherapy. In the same study, the authors claimed that response rate of the RT in patients with the plasma cell type was better than the other types due to higher tumoral activity of the plasma cell type (14).

Although Castleman disease has good prognosis with surgery, long term recurrences are reported in literature. Total excision was performed in the treatment of a patient with CD plasma cell variant, and recurrence occurred 11 months later. Re-excision and chemotherapy was given for the recurrence (15). We performed total excision for the left and near total excision for the right buccal masses in the treatment. During the three-year follow-up, neither recurrence nor additional systemic symptoms occurred.

Early diagnosis is very important in Castleman disease, especially in the multicentric and plasma cell subtypes, due to accompanying systemic disorders with high mortality, potential of malignant transformation and high recurrence rates. $\mathrm{CD}$, localized under buccal mucosa like in the current case, should be remembered in the differential diagnosis of asymptomatic masses in the oral cavity and the physician should be aware of concomitant disorders.

\section{References}

1. Gangopadhyay K, Mahasin ZZ, Kfoury H. Castleman disease (giant lymph node hyperplasia). Arch Otolaryngol Head Neck Surg 1997;123(10):1137-9.

2. Markou KD, Goudakos JK, Psillas G, Antoniadis A, Karasmanis I, Vital V, Nicolaou A. Castleman's disease of the neck: report of a case and review of the literature. B-ENT.2009;5(3):189-93.

3. Uskul B, Ertugrul M, Selvi A, Mihmanli A, Zindanci I, Turker H. A rare association: Castleman's disease and pemphigus vulgaris .Tuberk Toraks. 2005;53(2):172-6

4. Bowne WB, Lewis JJ, Filippa DA, Niesvizky R, Brooks $\mathrm{AD}$, Burt ME, et al. The management of unicentric and multicentric Castleman's disease. Cancer 1999;85(3):706-17.

5. Vries I, MS van Acht M, BJ Demeyere T, LM Lybeert M, Zoete J.P, Nieuwenhuijzen G. Neoadjuvant radiotherapy of primary irresectable unicentric Castleman's disease: a case report and review of the literature. Radiation Oncology 2010;5:7

6. Maslovsky I, Uriev L, Lugassy G. The heterogeneity of Castleman disease: report of five cases and review of the literature. Am J Med Sci 2000;320(4):292-5.

7. Gomes H, Huyett P, Laver N, Wein RO. A unique presentation of Epstein-Barr virusassociated Castleman's disease. Am J Otolaryngol 2013;34(3):262-4.

8. Chen YF, Zhang WD, Sun CZ, Ouyang D, Chen WK, Luo RZ, Wu MW. Clinical features and outcomes of head and neck castleman's disease. J Oral Maxillofac Surg 2012;70(10):2466-79.

9. Zawawi F, Varshney R, Haegert DG, Daniel SJ. Castleman's Disease: a rare finding in a pediatric neck. Int J Pediatr Otorhinolaryngol 2014;78(2):3702 
10. Karakoc O, Kilic E, Ilica T, Tosun F, Hidir Y. Castleman disease as a giant parapharyngeal mass presenting with dysphagia. J Craniofac Surg 2011;22(6):54-7.

11. Sanchez-Ros-Sanchez A, Infante-Cossio $P$, Gonzalez-Garcia A, Borrero-Martin JJ. Preoperative embolization for the treatment of cervical Castleman disease. J Craniofac Surg 2012;23(3):257-9.

12. Deshmukh M, Bal M, Deshpande P, Jambhekar NA Synchronous squamous cell carcinoma of tongue and unicentric cervical Castleman's disease clinically mimicking a stage IV disease: a rare association or coincidence? Head Neck Pathol 2011;5(2):180-3

13. Maruyama S, Hao N, Cheng J, Horino K, Ohnishi M, Fukushi M, Fujii M, Saku T. Castleman's disease of the buccal mucosa: report of a case and review of the literature of head and neck cases. Oral Surg Oral Med Oral Pathol Oral Radiol Endod 2002;93(3):305-10.

14. Bowne WB, Lewis JJ, Filippa DA, Niesvizky R, Brooks AD, Burt ME, et al. The manage- ment of unicentric and multicentric Castle- man's disease: a report of 16 cases and a review of the literature. Cancer 1999; 85(3):706-17.

15. de Vries IA, Van Acht MM, Demeyere T, Lybeert ML, de Zoete JP, Nieuwenhuijzen GA. Neoadjuvant radiotherapy of primary irresectable unicentric Castleman's disease: a case report and review of the literature. Radiat Oncol 2010;2:5-7 